\title{
PANCASILA AND THE DIGNITY OF HUMANKIND $^{1}$
}

\author{
Dicky Sofjan \\ Indonesian Consortium for Religious Studies (ICRS), Graduate School, \\ Universitas Gadjah Mada (UGM) \\ <dickysofjan@ugm.ac.id>
}

\section{Introduction}

I have been tasked today to present my thoughts on the correlation between Pancasila, which is Indonesia's state ideology, and human dignity. Indonesians, since gaining independence in 1945, have established Pancasila as their state ideology and political philosophy, which encompasses the rights and responsibilities of its citizens without discrimination based on religion or creed, gender, race or ethnicity, socioeconomic status or whatsoever.

Derived from Sankrit, the name "Pancasila" means "the five main principles'. The five principles are: 1)

1 This article was submitted to an international conference at Christ College, Oxford University, England, entitled "Human Dignity for Everyone Everywhere: Founding Figures, Foundations, and the Uses of Human Dignity" on August 3-4, 2018. I would like to thank Jane Wise of Brigham Young University, who read the paper in the said conference.
Belief in the Unity of Deities; 2) Just and civilized humanity; 3) Unity of Indonesia; 4) Democracy led by wisdom through deliberation of the elected representatives; 5) Social justice for all Indonesians. Invariably, Pancasila has become Indonesia's uniting force for the 265 million people living on 3000 islands or so out of the more than 17,000 islands. Out of the 265 million, Indonesians are endowed with more than 500 ethno, psycholinguistic groups, each having its own culture, language or dialect, tradition and custom.

The five main principles have governed the people of Indonesia for 75 years now, owing to the veracity of the universal message that Pancasila aspires to. The founding figures of the nation seemed mindful of the diversity of the people and their multitude of traditions and beliefs. They were vehemently anti-colonialism and anti-imperialism, 
yet ardent supporters of the idea of universalism and human dignity. Their vision of the state for Indonesia was based on an inclusive, plural, humane and just view of the world. Thus, they did not bow to the political pressures and persuasion to turn Indonesia into an Islamic Republic or to make Shari'a as the law of the land.

If Pancasila's political philosophy were to be scrutinized closely and objectively, it is clear that all its principles and values are consistent with the Indonesian nation's religious zeal or spiritual proclivity. Almost all kinds of "world religions" have been flourishing throughout the history of the Indonesian archipelago, with people freely embracing the religion of their choosing.

Old sacrosanct temple structures (such as the 8-9th century Borobudur and Prambanan), the numerous picturesque churches and spectacular mosques provide clear testimony to the people's varied religious and spiritual persuasion and expression. The blossoming of these major world religions of course run in parallel to the longstanding 'local religions' or indigenous, tribal and ancestral beliefs. The Indonesian Ministry of Religious Affairs has identified almost 400 of such beliefs that exist across the archipelago.

Such religious diversity and richness in the multitude of spiritual practices are perfectly congruent with the kind of biodiversity found in the country's vast number of islands, oceans and under its deep blue seas. With the diversity of its people, varied animal, plant and tree species, and bountiful geography, Indonesia is undoubtedly one of the most intriguing places on earth.

\section{Pancasila Knows No Othering}

One of the appeals of Pancasila resides in its humanism and universalism. While its humanism draws on the varied race and ethnicities and the time-honored practice of cultural pluralism, its universal appeal derives from the very essence of the Indonesian spiritual and pluralistic worldview. The successful fusion of culture, religion, spirituality and modernity has unmistakably placed Indonesia on the world map. It is said that in one or two decades time, Indonesia could be become the fourth or fifth largest economy of the world.

There is therefore no reason why Indonesians should not be grateful or proud of the plentiful God-given gifts in the form of their natural and spiritual endowments, which makeup for their unique position in the world. Having stated that, the building of confidence among the rather timid and introverted Indonesians is necessary to contribute to the upholding of human dignity.

It could be argued that Pancasila has become a way for Indonesians to perceive reality beyond their own. It is for the most part a manner in which 
individuals and groups perceive us as them, and them as us. Pancasila thus knows no 'othering', as it merely compartmentalizes human beings into false classification and polarization, and subsequently breeds unwarranted privileges and discrimination in society.

It was unequivocally designed by the nation's founding figures as an inclusive and pluralistic ideology that meant to protect and shelter minority groups and potentially vulnerable communities from the possibility of a wretched war of 'all against all'.

Through the lens of Pancasila, Indonesians are able to assume the worth and value of individuals and peoples as being necessary and indispensable. It also helps them to gain the realization that they are borne and bestowed by the Creator to humanity based on Divine Will and Wisdom. In Islam, which is the religion most professed by Indonesians, Quranic injunctions point to the necessity of diversity as being part of Divine Will and Wisdom. In Al-Maidah (5:48), the Quran states: "Had Allah willed, He would have made you into a single nation."

It is therefore almost imperative for Muslims to believe that diversity of religion, spiritual expressions, race, ethnicity, gender, and all kinds of personal preferences are part and parcel of Divine Will and Wisdom. To contest, challenge and resist that would not only prove futile, but would tantamount to blasphemy.

Pancasila is henceforth not against Islam nor any other religion or beliefs. Pancasila assumes the absence of human dignity in colonialism, feudalism, racism, corruption and exploitation. It diametrically contradicts the very logic of apartheid or any and all forms of discrimination or violation against the rights of others.

Simply put, Pancasila promotes a dignified way of life and living for all beings, both humans and nonhumans. Out of all the species in the planet, we, humans with the perfect ability to discern reality, should be the one to first recognize that dignity should be properly accorded to God, nature and the entire created species on the planet, including humankind.

Despite the current challenge of religious conservatism, post-truth society and the failure of global Capitalism to bring equity, contentment and sense of wholesomeness, it is upon us as humankind to rethink how to build and sustain a dignified way of life for future generations to come.[] 